\title{
Regulacje prawne w zakresie szczepień ochronnych przeciwko COVID-19 - problemy wybrane
}

\section{Wprowadzenie}

Trwająca od końca 2019 r. światowa epidemia wirusa SARS-CoV-2 stanowi wydarzenie bezprecedensowe $\mathrm{w}$ najnowszej historii człowieka. Wypada, a nawet trzeba, tu wyjaśnić, że wspomniany wirus to nazwa czynnika chorobotwórczego należącego do koronawirusów, czyli grupy wirusów RNA. Koronawirus SARS-CoV wywołuje chorobę SARS (zespół ciężkiej, ostrej niewydolności oddechowej), a SARS-CoV-2 prowadzi do rozwinięcia się ostrej choroby zakaźnej dróg oddechowych, nazwanej COVID-1919 . Co prawda pod względem liczby zachorowań oraz spowodowanych zgonów obecnie trwająca epidemia ustępuje zarówno pustoszącej całe regiony Europy w XIV w. dżumie, określanej obrazowo czarną śmiercia, epidemiom grypy i ospy w Nowym Świecie w wieku XV, jak i epidemii grypy hiszpanki w 1918 r., to obszar jej występowania oraz wpływ na życie człowieka jest niepodważalnie wyjątkowy. Przyczynił się do tego stanu rzeczy paradoksalnie rozwój nauk biomedycznych oraz szczególna rola mediów.

\footnotetext{
* Piotr Szudejko, dr, e-mail: szudejko@legalfactory.pl,https://orcid.org/0000-00025259-8759.

** Paulina Jachimowicz-Jankowska, dr, Uniwersytet im. Adama Mickiewicza w Poznaniu, e-mail: janpkows@amu.edu.pl, https://orcid.org/0000-0002-6061-1220.

${ }^{1}$ Zob. szerzej: M. Kostyńska, Koronawirus SARS-CoV-2 - słowniczek pojęć, które warto znać, https://www.medonet.pl/zdrowie,koronawirus-sars-cov-2---slowniczek-pojec-ktore-warto znac,artykul,70847711.html (dostęp: 28 X 2021).
} 
W tej wyjątkowej sytuacji aktualizują się obowiązki państwa w zakresie ochrony życia i zdrowia obywateli, zarówno w obszarze uchwalania stosownego prawa, jak i jego wykonywania. Jest to niezwykle istotne, bowiem początkowo wprowadzony w Polsce stan zagrożenia epidemicznego, który później przekształcono w obowiązujący stan epidemii, aktualnie znowu przybiera na sile, co wyraża się przede wszystkim w liczbie nowych zachorowań, jak i zgonów. Jak się wydaje, remedium na wysoki stopień zachorowalności na COVID-19 stanowi możliwość wykonywania szczepień ochronnych przeciwko tej chorobie.

Rozważania dotyczące wyjątkowości epidemii w powiązaniu z ochroną zdrowia jako szczególnym sposobem ochrony życia obywateli trudno prowadzić w oderwaniu od analizy przepisów Konstytucji Rzeczypospolitej Polskiej z dnia 2 kwietnia 1997 r. ${ }^{2}$ Prawo do ochrony życia zostało określone przecież w art. 38 Konstytucji $\mathrm{RP}$, który statuuje obowiązek państwa w zakresie prawnej ochrony każdego człowieka. Przed uchwaleniem Konstytucji RP prawo do ochrony życia zostało wywiedzione z zasady demokratycznego państwa prawnego w orzeczeniu Trybunału Konstytucyjnego (TK) ${ }^{3}$. Trybunał przywołał obszerną podstawę aksjologiczną dla istnienia tego prawa, wskazując również na istnienie przepisów szczególnych, które realizują powyższe prawo - jak chociażby przepisy zakazujące wykonywania kary śmierci na kobietach ciężarnych. Brzmienie tego artykułu wyznacza zakres podmiotowy zasady prawa do ochrony życia, która obejmuje zarówno obywateli, jak i cudzoziemców znajdujących się na terenie Polski.

Wśród przedstawicieli polskiej doktryny panuje zgoda co do faktu, że najistotniejszym prawem, zagwarantowanym w Konstytucji RP jest wyrażona w art. 30 zasada godności człowieka, będąca źródłem wszystkich pozostałych praw i wolności. Truizmem jest jednak stwierdzenie, że istnienie jest niezbędne dla realizacji przysługujących jednostce uprawnień. Zmarli nie posiadają już żadnych praw i nie mogą ich egzekwować również ich spadkobiercy. Dziedziczeniu podlegają bowiem wyłącznie niektóre roszczenia.

Konstytucyjna forma prawa do ochrony życia nie przesądza jeszcze o zakresie obowiązków państwa. W szczególności nie można przesądzić wyłącznie na tej podstawie, czy państwo ma obowiązek aktywnego

\footnotetext{
${ }^{2}$ Dz.U. Nr 78, poz. 483 z zm., dalej „Konstytucja RP”.

${ }^{3}$ Orzeczenie TK z 28 V 1997 r., K 26/96, OTK 1997, nr 2, poz. 19.
} 
działania w celu redukcji obiektywnych zagrożeń dla życia obywateli, czy też wystarczające jest wprowadzenie stosownej reakcji karnej. Na rozstrzygniecie powyższego dylematu pozwala natomiast wykładnia innych przepisów Konstytucji RP. W istotnym tu zakresie kluczowe znaczenie ma art. 68 Konstytucji RP, ustanawiający prawo do ochrony zdrowia. Źródło tej normy można dostrzec w przepisach Powszechnej Deklaracji Praw Człowieka ${ }^{4}$. Prawo do ochrony zdrowia stanowi rozwinięcie, a także gwarancję realizacji prawa do ochrony życia, w szczególności w sytuacji, gdy stan zdrowia może stanowić bezpośrednie ryzyko śmierci.

Bez wątpienia koronawirus SARS-CoV-2 wywołujący chorobę COVID-19 ma wpływ na obniżenie bezpieczeństwa zdrowotnego społeczeństwa. Tym bardziej w celu powstrzymania rozprzestrzeniania się zachorowań istotne znaczenie ma reakcja władz państwowych w tym zakresie. Niemniej istotna jest także racjonalna postawa i odpowiednie działanie wszystkich obywateli wobec istniejącego już zagrożenia.

Celem niniejszego artykułu jest analiza i ocena regulacji prawnych dotyczących szczepień ochronnych przeciwko COVID-19 wprowadzonych w Polsce. W tym zakresie odniesiono się do fundamentalnych założeń dotyczących konstytucyjnego modelu ochrony zdrowia w Polsce. Badaniami objęto rozwiązania prawne przyjęte $\mathrm{w}$ związku $\mathrm{z}$ epidemią COVID-19. Dokonano także oceny zgodności sposobu dystrybucji szczepionek przeciwko SARS-CoV-2 z konstytucyjnym modelem ochrony zdrowia w świetle przepisów de lege lata, a ponadto sformułowano na tym tle wnioski i postulaty de lege ferenda.

\section{Konstytucyjny model ochrony zdrowia}

\subsection{Prawo do ochrony zdrowia - ogólne założenia}

Zgodnie z treścią art. 68 ust. 1 Konstytucji RP prawo do ochrony zdrowia przysługuje każdemu człowiekowi, ma zatem - podobnie jak prawo do ochrony życia - charakter powszechny. Tym samym wszystkim obywatelom przysługuje w ramach systemu zdrowia konstytucyjne podmiotowe

${ }^{4}$ K. Prokop, Prawo do ochrony zdrowia w świetle art. 68 Konstytucji RP, w: Uwarunkowania prawne, ekonomiczne i socjologiczne funkcjonowania wybranych systemów ochrony zdrowia, pod red. T. Mróz, Białystok 2011, s. 37. 
prawo do należytej ochrony zdrowia ${ }^{5}$. Postanowienia konstytucyjne dotyczące prawa do ochrony zdrowia uregulowano w ramach rozdziału II Konstytucji RP pt. „[w]olności, prawa i obowiązki człowieka i obywatela", przy doprecyzowaniu, że są to „[w]olności i prawa ekonomiczne, socjalne i kulturalne". Oznacza to, że „[p]rawo do ochrony zdrowia nie zostało zaliczone do podstawowych praw niemajątkowych (osobistych), o których mowa w art. 233 ust. 1 Konstytucji RP"6.

Interpretacji art. 68 ust. 1 Konstytucji RP dokonał także TK. W wyroku z dnia 7 stycznia 2004 r. $^{7}$ TK podniósł, że „[t]reścią prawa do ochrony zdrowia nie jest naturalnie jakiś abstrakcyjnie określony [...] stan „zdrowia" poszczególnych jednostek, ale możliwość korzystania z systemu ochrony zdrowia, funkcjonalnie nakierunkowanego na zwalczanie i zapobieganie chorobom, urazom i niepełnosprawności". Poza tym w tym samym wyroku, w kontekście zakresu podmiotowego - zagwarantowanego w analizowanym ustępie 1 art. 68 Konstytucji RP - określonego szeroko jako prawa człowieka, TK wskazał, iż „Konstytucja wyklucza jakiekolwiek wyłączenia podmiotowe z zakresu jego działania". Prawo to przysługuje zatem tak ubezpieczonym, jak i nieubezpieczonym. Bez wątpienia wiąże się ono $\mathrm{z}$ innymi prawami konstytucyjnymi, w tym z godnością człowieka i prawną ochroną życia ${ }^{8}$. Natomiast w wyroku z dnia 23 marca 1999 r. ${ }^{9}$ TK stwierdził, że "należy wywieść podmiotowe prawo jednostki do ochrony zdrowia oraz obiektywny nakaz podejmowania przez władze publiczne takich działań, które są konieczne dla należytej ochrony i realizacji tego prawa".

Warto tu zauważyć, że w obowiązującym krajowym porządku prawnym stosuje się pojęcie "ochrona zdrowia” zarówno w Konstytucji RP, aktach prawa międzynarodowego ratyfikowanych przez Polskę, jak i w licznych ustawach ${ }^{10}$. Przy czym jednak żaden akt prawny nie przedstawia

${ }^{5}$ M. Dercz, H. Izdebski, Organizacja ochrony zdrowia Rzeczypospolitej Polskiej w świetle obowiazujacego ustawodawstwa, Warszawa-Poznań 2001, s. 10-18. Zob. także wyrok Sądu Najwyższego z 21 XII 2004, I CK 320/04.

${ }^{6}$ L. Bosek, Komentarz do art. 68, w: Konstytucja RP. Tom I. Komentarz do art. 1-86, pod red. M. Safjana, L. Boska, Warszawa 2016, teza 1.

7 Sygn. K 14/03, OTK-A 2004, nr 1, poz. 1.

${ }^{8}$ Por. B. Banaszak, Komentarz do art. 68, w: Konstytucja Rzeczypospolitej Polskiej. Komentarz, Warszawa 2012, teza 1.

${ }^{9}$ Sygn. K 2/98, OTK 1999, nr 3, poz. 38.

${ }^{10}$ Przeglądu tych regulacji prawnych dokonuje K. Wojtczak, Kompetencje i zadania jednostek samorzadu terytorialnego w zakresie bezpieczeństwa zdrowia ludności, „Studia Prawa Publicznego" 2018, nr 3(23), s. 9 i n. 
definicji powyższego terminu, mimo ewidentnej potrzeby praktycznej ${ }^{11}$. Termin "ochrona zdrowia” w ujęciu polskiej doktryny uwzględnia kilka elementów, przy czym istotne znaczenie mają: promocja zdrowia i opieka zdrowotna. Można stwierdzić, że ochrona zdrowia opiera się na sumie wiedzy o obowiązujących standardach i zasadach zapobiegania oraz na strategii postępowania diagnostyczno-terapeutycznego w zwalczaniu chorób trapiących ludzkość. Podstawowym zaś celem całego systemu ochrony zdrowia jest zapewnienie bezpieczeństwa zdrowotnego ludzi. Dokonuje się to przez zaspokajanie indywidualnych potrzeb medycznych, działania mające na celu zapewnienie odpowiednich warunków egzystencji, pracy i innych aspektów życia, które zapobiegają lub zmniejszają ryzyko utraty zdrowia ${ }^{12}$. Wypada zwrócić zatem uwagę jeszcze na pojęcie "systemu ochrony zdrowia”, który "[...] obejmuje w aspekcie funkcjonalnym - zorganizowany i skoordynowany zespół działań zdrowotnych, którego celem jest realizacja świadczeń i usług profilaktyczno-leczniczych i rehabilitacyjnych, mających na celu zabezpieczenie i poprawę zdrowia jednostek i zbiorowości, a w aspekcie instytucjonalnym - ogół podmiotów i instytucji powołanych do organizowania, finansowania i udzielania świadczeń opieki zdrowotnej"13. Natomiast "[w] ładze publiczne za pomoca systemu ochrony zdrowia powinny czuwać nad stanem zdrowia ludności, nad warunkami jej życia i pracy oraz powinny przeciwdziałać zjawiskom szkodliwym"14. Omówione powyżej zagadnienia, jak się okazuje, mają fundamentalne znaczenie $\mathrm{w}$ zakresie problematyki związanej $\mathrm{z}$ wprowadzaniem przez władze publiczne określonych działań w walce $\mathrm{z}$ wirusem SARS-CoV-2 wywołującym chorobę COVID-19. To na władzach publicznych spoczywa obowiązek stworzenia odpowiednich instytucji i rozwiązań umożliwiających zapobieganie tej chorobie. Tym bardziej celowe jest wprowadzenie możliwości odpowiedniego jej zwalczania, poprzez umożliwienie korzystania ze szczepień ochronnych w tym zakresie.

${ }^{11}$ Por. J. Nosko, Promocja zdrowia i ochrona zdrowia jako zadanie własne samorzadu terytorialnego, cz. 1, "Zdrowie Publiczne" 2000, nr 4, s. 151 i n.; Eadem, Promocja zdrowia i ochrona zdrowia jako zadanie własne samorzadu terytorialnego, cz. 2, "Zdrowie Publiczne” 2000, nr 5, s. 187 i n.

${ }^{12}$ R. Michalska-Badziak, Ochrona zdrowia. Zagadnienia ogólne, w: Prawo administracyjne materialne, pod red. Z. Duniewskiej, B. Jaworskiej-Dębskiej, M. Stahl, Warszawa 2014, s. 227.

${ }_{13}$ Tak: M. Dercz (red.), H. Izdebski, T. Rek, Prawo publiczne ochrony zdrowia, Warszawa 2013, s. 33.

${ }^{14}$ Ibidem, s. 32. 


\subsection{Zasada równego dostępu do świadczeń opieki zdrowotnej, finansowanej ze środków publicznych}

W ustępie 2 art. 68 Konstytucji RP określono, że władze publiczne zobowiązane są do zapewnienia równego dostępu do świadczeń zdrowotnych, finansowanych ze środków publicznych, przy czym warunki i zakres udzielania świadczeń ma zostać określony w ustawie. Na kanwie tego przepisu można sformułować kilka uwag.

Po pierwsze, $\mathrm{w}$ analizowanym przepisie, stanowiącym normę prawną o charakterze programowym, ustawodawca nakłada na władze publiczne obowiązek stworzenia systemu funkcjonalnego i efektywnego, a zatem zapewniającego rzeczywistą realizację prawa do ochrony zdrowia. Konstytucja RP nie przesądza natomiast, jaki model ochrony zdrowia powinien zostać przyjęty, wybór w tym zakresie należy do kompetencji ustawodawcy, który powinien stworzyć system nie tylko efektywny, lecz także pozwalający zapewnić równy dla wszystkich obywateli dostęp do świadczeń opieki zdrowotnej ${ }^{15}$.

Po drugie, „[ [d]ostęp do świadczeń zdrowotnych ma być równy ${ }^{16}$, a zatem ustawodawca, realizując konstytucyjny obowiązek władzy określony w art. 68 ust. 2 Konstytucji RP, nie może pozostawiać wątpliwości co do tego, jaki jest zakres świadczeń medycznych przysługujących beneficjentom publicznego systemu opieki zdrowotnej, a w konsekwencji nie może wprowadzać - w ramach tego systemu - modelu pozwalającego na dyferencjację świadczeń w wypadku występowania podobnych potrzeb zdrowotnych. W polskich realiach problemem jest jednak zapewnienie równego dostępu do świadczeń takiej samej jakości"17.

Po trzecie, przyjęta koncepcja równego dostępu nie została przez ustrojodawcę wystarczająco precyzyjnie określona. Zgodnie z definicją słownikową równy oznacza między innymi: „równający się czemuś pod względem liczby, ilości, wielkości oraz niefaworyzujący nikogo"18.

\footnotetext{
${ }^{15}$ Szerzej zob. D.E. Lach, Zasada równego dostępu do świadczeń opieki zdrowotnej, Warszawa 2011, s. 24 i n.

${ }^{16}$ Por. przytaczany już wyrok TK z 7 I 2004 r., K 14/03, OTK-A 2004, nr 1, poz. 1.

${ }^{17}$ E. Bagińska, Odpowiedzialność za brak dostępności do świadczeń zdrowotnych należnych w ramach systemu opieki zdrowotnej finansowanej ze środków publicznych. Odpowiedzialność podmiotów będacych organizatorami systemu opieki zdrowotnej za brak dostępności świadczeń zdrowotnych, w: Odpowiedzialność prywatnoprawna. System Prawa Medycznego, t. 5, pod red. E. Bagińskiej, Warszawa 2021, s. 1049-1050.

${ }^{18}$ Stownikjęzyka polskiego PWN, hasło: równy, https://sjp.pwn.pl/sjp/rowny-I;2517839. html (dostęp: 28 X 2021).
} 
Zasada równości wobec prawa, określona w art. 32 Konstytucji RP wskazuje natomiast, że wszyscy mają prawo do równego traktowania przez władze publiczne oraz że "nikt nie może być dyskryminowany w życiu politycznym, społecznym lub gospodarczym z jakiejkolwiek przyczyny". Z powyższego wynika, że ustrojodawca posługuje się terminem równy w najszerszym znaczeniu, bliskim arystotelesowskiej koncepcji sprawiedliwości dystrybutywnej.

W tym kontekście trudno zrozumieć dodatkowe zastrzeżenie poczynione w treści art. 68 ust. 2, że dostęp do świadczeń zdrowotnych powinien być zapewniony obywatelom niezależnie od ich sytuacji materialnej. Być może celem tego zabiegu było wskazanie w sposób szczególny na kwestie materialne i wyróżnienie tego aspektu pośród innych przesłanek udzielania świadczeń zdrowotnych, niemniej na uwagę zasługuje fakt, że świadczenia zdrowotne finansowane ze środków publicznych są udzielane co do zasady osobom posiadającym ubezpieczenie zdrowotne. Materialny niedostatek zatem nie stanowi wystarczającej przesłanki, by otrzymywać wymienione świadczenia. Należy zatem przyjąć, że celem dodania powyższego zastrzeżenia było wykluczenie możliwości ustawowego uzależnienia zakresu przysługujących obywatelowi świadczeń od sumy składek, wniesionych do systemu ubezpieczenia zdrowotnego bądź od częściowej partycypacji w kosztach udzielenia świadczenia, co stanowi konstytucyjne źródło istotnej zasady systemu świadczeń zdrowotnych - zasady solidarności.

\subsection{Konstytucyjne wyjątki od zasady równego dostępu do świadczeń: dzieci, kobiety ciężarne, osoby niepełnosprawne i w podeszłym wieku}

Zasada równego dostępu do świadczeń zdrowotnych nie ma bezwzględnego charakteru. Zgodnie z brzmieniem art. 68 ust. 3 Konstytucji $\mathrm{RP}$, władze publiczne powinny zapewnić szczególną opiekę zdrowotną dzieciom, kobietom ciężarnym, osobom niepełnosprawnym oraz w podeszłym wieku, co można określić jako nakaz pozytywnej dyskryminacji. Norma powyższa może budzić wątpliwości z trzech powodów.

Po pierwsze - nie jest oczywiste, jaki charakter ma przedstawiony katalog wyjątków: czy jest to katalog zamknięty, czy też otwarty. W treści przepisu nie występuje sformułowanie w szczególności ani inne o podobnym 
znaczeniu, co nakazywałoby przyjąć, że jest to katalog otwarty. Taki sam wniosek można wyprowadzić z zasady zakazu rozszerzania wyjątków.

Tym niemniej, powyższe kategorie wyjątków od zasady równego dostępu do świadczeń zdrowotnych można uznać za realizację zasady wyrażonej w art. 2 Konstytucji RP, zgodnie z którym państwo powinno podejmować aktywne działania w celu urzeczywistniania zasady sprawiedliwości społecznej.

Po drugie - wśród przesłanek uzyskania szczególnej opieki zdrowotnej nie znalazły się szczególne potrzeby zdrowotne obywatela. Oznacza to, że programy specjalne, w ramach których udzielane są świadczenia zdrowotne osobom dotkniętym określonym schorzeniom, a jednocześnie nienależącym do żadnej z wymienionych w ust. 3 grup i które nie są wykluczone społecznie (na przykład pacjentom cierpiącym na choroby nowotworowe), należy uznać za niezgodne z art. 68 ust. 2 i 3 Konstytucji RP, godzą one bowiem w zasadę równego dostępu do świadczeń zdrowotnych.

Po trzecie - nie jest jasne, jakie osoby można zaliczyć do dwóch uprzywilejowanych pozytywnie grup: niepełnosprawnych oraz osób w podeszłym wieku. Niepetnosprawność może być bowiem rozumiana zarówno w ujęciu formalnym, jak i materialnym. Aspekt formalny wyznacza wydanie stosownego orzeczenia o stopniu niepełnosprawności w trybie określonym w Ustawie z dnia 27 sierpnia 1997 r. o rehabilitacji zawodowej i społecznej oraz zatrudnianiu osób niepełnosprawnych ${ }^{19}$ oraz w przepisach wykonawczych do tej ustawy. W aspekcie materialnym natomiast niepełnosprawność dotyczy wyłącznie subiektywnego przekonania konkretnej osoby, że jej stan zdrowia określić można jako niepełnosprawność. W tym ujęciu niepełnosprawność staje się cechą znacznie bardziej niedookreśloną i zmienną. Dodatkową komplikację powoduje niepewność odnośnie do przyjętej przez ustrojodawcę koncepcji choroby (subiektywnej lub obiektywnej), co jednak przekracza ramy niniejszego artykułu.

Z założenia racjonalności ustawodawcy można wyprowadzić wniosek, że komentowana kategoria osób niepełnosprawnych opiera się na opisanym wyżej kryterium formalnym, a zatem pozytywna dyskryminacja dotyczy osób, które legitymują się orzeczeniem o posiadanym stopniu niepełnosprawności. Trudno bowiem wyobrazić sobie sprawnie funkcjonujący system udzielania świadczeń zdrowotnych, oparty na subiektywnych przekonaniach jego beneficjentów.

\footnotetext{
19 Tekst jedn. Dz.U. 2021, poz. 573.
} 
Zastosowana w komentowanym artykule kategoria podeszły wiek sprawia jeszcze większe problemy interpretacyjne. Przepisy konstytucyjne nie posługują się bowiem tym terminem, ani też bardziej obecnie popularnym: wiek senioralny. Zgodnie z dokumentami Światowej Organizacji Zdrowia (WHO) wiek podeszły oznacza 60-75 lat, wiek starczy 75-90 lat, natomiast wiek sędziwy więcej niż 90 lat. Przyjęcie takiej definicji oznaczałoby jednak, że organy państwa zobowiązane są do pozytywnej dyskryminacji obywateli w wieku od 60 do 75 lat, natomiast osoby starsze nie byłyby uprawnione do szczególnej opieki zdrowotnej. Przepisy ustawowe i podustawowe również nie pomagają w przeprowadzeniu wykładni komentowanego przepisu.

W art. 4 pkt 1 Ustawy z dnia 11 września 2015 r. o osobach starszych ${ }^{20}$ zawarta została definicja, zgodnie z którą osobą starszą jest osoba, która ukończyła 60 rok życia. Jednocześnie natomiast wprowadzony nowelizacją z dnia 12 czerwca 2016 r. art. 43a Ustawy z dnia 27 sierpnia 2004 r. o świadczeniach zdrowotnych opieki zdrowotnej finansowanych ze środków publicznych ${ }^{21}$ określa szczególne uprawnienia w zakresie bezpłatnego zaopatrzenia w leki, środki spożywcze specjalnego przeznaczenia żywieniowego i wyroby medyczne dla świadczeniobiorców, którzy ukończyli 75 rok życia. Niezależnie od powyższej niespójności, należy podkreślić, że obydwie ustawy zostały uchwalone niemal 20 lat po dniu uchwalenia Konstytucji RP, a zatem nie można ich uznać za oczywistą podstawę interpretacyjną terminu wiek podeszły. W tej sytuacji należy skłaniać się raczej do przyjęcia wykładni rozszerzającej, zgodnie z którą osoby w wieku podeszłym to osoby, które ukończyły 60 lat. Taka rozszerzająca wykładnia najpełniej realizować będzie prawa osób, określonych za pomocą nieprecyzyjnego terminu konstytucyjnego.

\subsection{Zasada aktywnej roli państwa w zwalczaniu zagrożeń epidemicznych}

Zasada aktywnej roli władzy państwowej w zakresie zwalczania zagrożeń epidemicznych, zdefiniowana $w$ art. 2 pkt 31 Ustawy z dnia 5 grudnia 2008 r. o zapobieganiu oraz zwalczaniu zakażeń i chorób

${ }^{20}$ Dz.U. 2015, poz. 1705.

${ }^{21}$ Zob. art. 1 Ustawy z dnia 18 III 2016 r. o zmianie ustawy o świadczeniach opieki zdrowotnej finansowanych ze środków publicznych oraz niektórych innych ustaw (Dz.U. 2016, poz. 652). 
zakaźnych u ludzi 22 jako „zaistnienie na danym obszarze warunków lub przesłanek wskazujących na ryzyko wystąpienia epidemii" - wyrażona jest w co najmniej dwóch regulacjach prawnych.

Otóż w ust. 4 art. 68 Konstytucji RP ustanowiony został obowiązek zwalczania chorób epidemicznych oraz zapobiegania negatywnym dla zdrowia skutkom degradacji środowiska przez władze publiczne. W kontekście treści art. 68 ust. 3 w związku z ust. 4 Konstytucji RP istotny wydaje się wzajemny stosunek powyższego przepisu oraz zasady równego dostępu do świadczeń wraz z przewidzianymi wyjątkami od tej zasady. Wykładnia celowościowa oraz systemowa nakazują przyjacć, że w komentowanym ustępie ustrojodawca ustanowił dwie kolejne grupy uprzywilejowanych obywateli: dotkniętych chorobami o charakterze epidemicznym oraz chorobami wynikającymi z degradacji środowiska. Nie ulega bowiem wątpliwości, że zarówno obowiązek zwalczania chorób epidemicznych, jak i zapobiegania negatywnym dla zdrowia skutkom degradacji środowiska znajdą swoje odzwierciedlenie w udzielaniu świadczeń zdrowotnych, które nie przysługują osobom spoza wyżej opisanych grup bądź też przysługują na mniej korzystnych zasadach. Przyjęcie innej interpretacji prowadziłoby do sprzeczności $\mathrm{z}$ celami, określonymi $\mathrm{w}$ powyższych przepisach, uniemożliwiałoby bowiem udzielanie świadczeń zdrowotnych w ramach programów zwalczania i profilaktyki przedmiotowych schorzeń.

Na marginesie można natomiast wskazać, że degradacja środowiska nie może powodować pozytywnych skutków dla zdrowia, a zatem termin negatywne skutki degradacji środowiska należy uznać za przykład tautologii.

Trzeba tutaj jeszcze dodać, że Konstytucja RP nie definiuje terminu zagrożenie epidemiczne, natomiast czyni to ustawodawstwo zwykłe. Odnosząc się jednak do znaczenia art. 68 ust. 4 Konstytucji RP, należy stwierdzić, że zwalczanie chorób epidemicznych jako obowiązek władz publicznych obejmuje działania prewencyjne, profilaktykę, dbałość o higienę, a ponadto kontrolę zakażeń oraz bezpośrednie leczenie tych chorób przez świadczenie opieki medycznej ${ }^{23}$.

Sposób realizacji obowiązku zwalczania chorób epidemicznych określony został w przytaczanej już ustawie o zapobieganiu oraz zwalczaniu zakażeń i chorób zakaźnych u ludzi. Przedstawienie całości

${ }^{22}$ Tekst jedn. Dz.U. 2021, poz. 2069, dalej „ustawa” lub „u.z.c.z.l.”.

${ }^{23}$ Szerzej zob. B. Banaszak, Komentarz do art. 68, w: Konstytucja Rzeczypospolitej Polskiej. Komentarz, Warszawa 2009 (Legalis). 
regulacji byłoby w tym miejscu niecelowe, wystarczające wydaje się skrótowe przybliżenie ogólnych zasad postępowania oraz bardziej szczegółowe przedstawienie sposobu dystrybucji szczepionek przeciwko SARS-CoV-2.

Zgodnie $z$ art. 3 ustawy jej przepisy stosuje się do zakażeń, chorób zakaźnych oraz biologicznych czynników chorobotwórczych, wyszczególnionych w wykazie, stanowiącym załącznik do ustawy. Ponadto, w przypadku wystąpienia zakażenia bądź choroby zakaźnej, które nie zostały wymienione w wykazie, minister właściwy do spraw zdrowia może wydać rozporządzenie, w którym określi te zakażenia i choroby oraz czynniki chorobotwórcze, o ile są znane, jednocześnie wskazując szczególny sposób postępowania świadczeniodawców systemu ochrony zdrowia oraz osób, narażonych na zakażenie lub zachorowanie. Zgodnie natomiast $\mathrm{z}$ art. 3 ust. 4 ustawy minister właściwy do spraw zdrowia może określić, w drodze rozporządzenia: (1) kryteria rozpoznawania, na potrzeby nadzoru epidemiologicznego, zakażenia lub choroby zakaźnej, w tym choroby szczególnie niebezpiecznej i wysoce zakaźnej, (2) metody zapobiegania zakażeniu lub chorobie zakaźnej oraz lekooporności biologicznych czynników chorobotwórczych wywołujących te choroby, (3) rodzaje badań laboratoryjnych niezbędnych do rozpoznania oraz identyfikacji biologicznych czynników chorobotwórczych - mając na względzie zapewnienie poprawności rozpoznawania zakażeń i chorób zakaźnych, potrzeby nadzoru epidemiologicznego oraz ochronę zdrowia publicznego. W tym zakresie objętym niniejszym artykułem obowiązuje rozporządzenie Ministra Zdrowia z dnia 31 grudnia 2021 r. w sprawie metody zapobiegania COVID-1924. Stosownie do $\S 1$ tego aktu wykonawczego wprowadza się metodę zapobiegania COVID-19 polegającą na wykonywaniu szczepień ochronnych. Ponadto, w myśl art. 4 ustawy Rada Ministrów może w drodze rozporządzenia określać programy zapobiegania i zwalczania zakażeń, chorób zakaźnych oraz lekoodpornych czynników chorobotwórczych. Powyższe programy powinny być uzasadnione sytuacją epidemiologiczną bądź koniecznością dostosowania się do programów o charakterze międzynarodowym.

Komentowana ustawa nakłada również szereg obowiązków na osoby przebywające na terytorium RP. W art. 5 określone zostały cztery rodzaje takich obowiązków: (1) odnoszące się do zabiegów medycznych (poddawanie się np. zabiegom sanitarnym, leczeniu, szczepieniom

${ }^{24}$ Dz.U. 2021, poz. 10. 
ochronnym, kwarantannie i izolacji), (2) odnoszące się do ograniczenia aktywności zawodowej (zaniechanie wykonywania prac, w których istnieje ryzyko zakażenia lub przeniesienia choroby zakaźnej na inne osoby), (3) odnoszące się do szczegółowych nakazów i zakazów organów Państwowej Inspekcji Sanitarnej w zakresie zapobiegania i zwalczania zakażeń i chorób zakaźnych, jak również (4) obowiązki udzielania informacji określonym organom. Analizując art. 5 ust. 1 i 2 ustawy, należy przyjąć, że obowiązki ustawowe tam typizowane w ślad za L. Boskiem "[...] traktować trzeba jako wyjątki od wolności i praw konstytucyjnych człowieka i obywatela, w szczególności wolność pracy, wolność majątkową i wolność działalności gospodarczej (art. 20-22 Konstytucji RP), jak i konstytucyjne prawa podmiotowe o charakterze wolnościowym i osobistym, w szczególności w wolność osobistą człowieka i wolność decydowania o samym sobie (art. 41 i art. 47 Konstytucji RP), wolność poruszania się i wyboru miejsca pobytu (art. 52 ust. 1 Konstytucji RP), wolność pracy (art. 20 i art. 65 Konstytucji RP) oraz wolność majątkową i wolność działalności gospodarczej (art. 20-22 Konstytucji RP)"25.

Zgodnie $z$ art. 2 pkt 26 ustawy szczepienie ochronne oznacza podanie szczepionki przeciw chorobie zakaźnej w celu sztucznego uodpornienia przeciwko tej chorobie. Jak przyjmuje się w doktrynie "[s]zczepienia ochronne są uznawane za jedno z największych osiągnięć medycyny i najskuteczniejszą ze znanych metod profilaktyki chorób zakaźnych. Powszechne zastosowanie szczepień przyczynia się bowiem nie tylko do zmniejszenia zachorowalności na wiele chorób zakaźnych, ale też do całkowitego wyeliminowania, w skali światowej, niektórych z nich (np. ospy prawdziwej)"26. Co więcej, „, [k]ryterium obligatoryjności pozwala podzielić szczepienia na obowiązkowe (obwarowane przymusem państwowym) oraz szczepienia zalecane (dobrowolne). Podział ten ma doniosłe znaczenie $z$ punktu widzenia podstaw kompensacji szkód związanych z podaniem szczepionki oraz możliwości stosowania przymusu państwowego. Nałożenie przez ustawodawcę na określone podmioty obowiązku poddania się szczepieniom jest uzasadnione powinnością państwa w zakresie dbałości o zdrowie i życie społeczeństwa jako całości, w tym poprzez skuteczną profilaktykę przed chorobami epidemicznymi (art. 68 ust. 4 Konstytucji RP). Jak się trafnie podkreśla

${ }^{25}$ L. Bosek, Komentarz do art. 5, w: Ustawa o zapobieganiu oraz zwalczaniu zakażeń i chorób zakaźnych u ludzi. Komentarz, pod red. L. Boska, Warszawa 2021, s. 3-7.

${ }^{26}$ E. Bagińska, K. Bączyk-Rozwadowska, U. Drozdowska, N. Karczewska-Kamińska, K. Krupa-Lipińska, op. cit., s. 534 i n. 
w literaturze, szczepienia obowiązkowe mają na celu nie tylko ochronę konkretnych, poddawanych nim osób, ale całej populacji, w tym zwłaszcza podmiotów, które ze względu na przeciwwskazania zdrowotne nie mogą przyjąć szczepionki bądź, pomimo zaszczepienia, nie wykształcają odporności immunologicznej"27.

W kontekście natomiast czterech wskazanych powyżej obowiązków, a także uwzględniając zarówno podjętą problematykę, jak i uwagi komentatorskie $^{28}$ nie sposób się nie zgodzić, że obowiązek poddania się szczepieniom ochronnym ma kluczowe znaczenie z medycznego punktu widzenia. Obowiązek ten stanowi ponadto ukierunkowany sposób na przeciwdziałanie i zwalczanie epidemii. Poza tym trzeba zwrócić uwagę, iż w art. 36 ust. 1 analizowanej ustawy ustawodawca konstruuje środek przymusu bezpośredniego, zgodnie z którym wobec osoby, która nie poddaje się m.in. obowiązkowi szczepienia, a u której podejrzewa się lub rozpoznano chorobę szczególnie niebezpieczną i wysoce zakaźna, stanowiącą bezpośrednie zagrożenie dla zdrowia lub życia innych osób, może być zastosowany środek przymusu bezpośredniego polegający na przytrzymywaniu, unieruchomieniu lub przymusowym podaniu leków.

\subsection{Zarys rozwiązań ustawowych i podustawowych w zakresie modelu ochrony zdrowia}

Model ochrony zdrowia w polskich regulacjach prawnych został ujęty w sposób szeroki. Oznacza to, że w ramach ochrony zdrowia istnieje rozbudowany system unormowań prawnych ${ }^{29}$. Ze względu na wspomnianą wielość przepisów prawnych odnoszących się do problematyki zdrowotnej główny akcent położono na wyeksponowanie tutaj ustaw.

W przyjętym modelu ochrony zdrowia można wskazać następujące obszary: (1) działalność lecznicza i podmioty lecznicze, (2) finansowanie świadczeń opieki zdrowotnej, (3) prawa pacjenta i Rzecznik Praw Pacjenta, (4) system informacji w ochronie zdrowia, (5) zdrowie publiczne,

\footnotetext{
${ }^{27}$ Ibidem, s. 534.

${ }^{28}$ Szerzej zob. L. Bosek, Komentarz do art. 5, s. 3-7.

${ }^{29}$ Dotyczy to zarówno: po pierwsze - ustaw, jak i po drugie - aktów podustawowych, a zatem innymi słowy: „[...] aktów wykonawczych służących wykonywaniu ustaw (czyli do rozporządzeń) lub aktów prawa wewnętrznego albo aktów prawa miejscowego, bo tylko tym trzem źródłom prawa można przypisać miano aktu podustawowego, co oznacza, że podstawa do ich wydania znajduje się w obowiązującej ustawie". Tak: M. Kaczocha, Redagowanie aktów podustawowych. Zagadnienia praktyczne, Warszawa 2020, s. 9.
} 
(6) ratownictwo medyczne, (7) Państwowa Inspekcja Sanitarna, (8) choroby zakaźne, (9) ubezpieczenia dotyczące zdrowia, (10) prawo farmaceutyczne i wyroby medyczne, (11) nałogi, czyli alkoholizm, narkomania i nikotynizm, (12) zdrowie psychiczne, (13) publiczna służba krwi, (14) zawody medyczne i pracownicy służby zdrowia, (15) uzdrowiska i lecznictwo uzdrowiskowe, (16) demografia zdrowia, (17) informatyzacja ochrony zdrowia, (18) szczególne grupy osób, czyli dzieci, kobiety w ciąży, niepełnosprawni, osoby starsze, (19) chowanie zmarłych.

Organizację polskiego modelu ochrony zdrowia reguluje wiele ustaw $^{30}$. Bez wątpienia ważne znaczenie w kontekście unormowań

${ }^{30} \mathrm{~W}$ układzie chronologicznym są to m.in.: Ustawa z dnia 31 I 1959 r. o cmentarzach i chowaniu zmarłych (tekst jedn. Dz.U. 2020, poz. 1947), Ustawa z dnia 26 X 1982 r. o wychowaniu w trzeźwości i przeciwdziałaniu alkoholizmowi (tekst jedn. Dz.U. 2021, poz. 1119), Ustawa z dnia 19 IV 1991 r. o izbach aptekarskich (tekst jedn. Dz.U. 2021, poz. 1850), Ustawa z dnia 7 I 1993 r. o planowaniu rodziny, ochronie płodu ludzkiego i warunkach dopuszczalności przerywania ciąży (Dz.U. Nr 17, poz. 78), Ustawa z dnia 19 VIII 1994 r. o ochronie zdrowia psychicznego (tekst jedn. Dz.U. 2020, poz. 685), Ustawa z dnia 9 XI 1995 r. o ochronie zdrowia przed następstwami używania tytoniu i wyrobów tytoniowych (tekst jedn. Dz.U. 2021, poz. 276), Ustawa z dnia 5 XII 1996 r. o zawodach lekarza i lekarza dentysty (tekst jedn. Dz.U. 2021, poz. 790), Ustawa z dnia 22 VIII 1997 r. o publicznej służbie krwi (tekst jedn. Dz.U. 2021, poz. 1749), Ustawa z dnia 27 VIII 1997 r. o rehabilitacji zawodowej i społecznej oraz zatrudnianiu osób niepełnosprawnych (tekst jedn. Dz.U. 2021, poz. 573), Ustawa z dnia 25 VI 1999 r. o świadczeniach pieniężnych z ubezpieczenia społecznego w razie choroby i macierzyństwa (tekst jedn. Dz.U. 2021, poz. 1133), Ustawa z dnia 27 VII 2001 r. o diagnostyce laboratoryjnej (tekst jedn. Dz.U. 2021, poz. 886), Ustawa z dnia 6 IX 2001 r. - Prawo farmaceutyczne (tekst jedn. Dz.U. 2021, poz. 1977), Ustawa z dnia 27 VIII 2004 r. o świadczeniach opieki zdrowotnej finansowanych ze środków publicznych (tekst jedn. Dz.U. 2021, poz. 1285), Ustawa z dnia 29 VII 2005 r. o przeciwdziałaniu narkomanii (tekst jedn. Dz.U. 2020, poz. 2050), Ustawa z dnia 8 IX 2006 r. o Państwowym Ratownictwie Medycznym (tekst jedn. Dz.U. 2021, poz. 2053), Ustawa z dnia 6 XI 2008 r. o prawach pacjenta i Rzeczniku Praw Pacjenta (tekst jedn. Dz.U. 2020, poz. 849), Ustawa z dnia 6 XI 2008 r. o akredytacji w ochronie zdrowia (tekst jedn. Dz.U. 2016, poz. 2135),Ustawa z dnia 6 XI 2008 r. o konsultantach w ochronie zdrowia (tekst jedn. Dz.U. 2019, poz. 886), Ustawa z dnia 2 XII 2009 r. o izbach lekarskich (tekst jedn. Dz.U. 2021, poz. 1342), Ustawa z dnia 4 II 2011 r. o opiece nad dziećmi w wieku do lat 3 (tekst jedn. Dz.U. 2021, poz. 75), Ustawa z dnia 11 IV 2011 r. o działalności leczniczej (tekst jedn. Dz.U. 2021, poz. 711), Ustawa z dnia 28 IV 2011 r. o systemie informacji w ochronie zdrowia (tekst jedn. Dz.U. 2021, poz. 666), Ustawa z dnia 1 VII 2011 r. o samorządzie pielęgniarek i położnych (tekst jedn. Dz.U. 2021, poz. 628), Ustawa z dnia 15 VII 2011 r. o zawodach pielęgniarki i położnej (tekst jedn. Dz.U. 2021, poz. 479), Ustawa z dnia 22 XI 2013 r. o systemie powiadamiania ratunkowego (tekst jedn. Dz.U. 2021, poz. 268), Ustawa z dnia 11 IX 2015 r. o działalności ubezpieczeniowej i reasekuracyjnej (tekst jedn. Dz.U. 2021, poz. 1130), Ustawa z dnia 11 IX 2015 r. o zdrowiu publicznym (tekst jedn. Dz.U. 2021, poz. 1956), Ustawa z dnia 11 IX 2015 r. o osobach starszych (Dz.U. 2015, poz. 1705), ustawa z dnia 25 IX 2015 r. 
dotyczących szczepień ochronnych przeciwko COVID-19, a także epidemii mają dwie ustawy, mianowicie: (1) przytaczana już Ustawa z dnia 5 grudnia 2008 r. o zapobieganiu oraz zwalczaniu zakażeń i chorób zakaźnych u ludzi, (2) Ustawa z dnia 2 marca 2020 r. o szczególnych rozwiązaniach związanych z zapobieganiem, przeciwdziałaniem i zwalczaniem COVID-19, innych chorób zakaźnych oraz wywołanych nimi sytuacji kryzysowych ${ }^{31}$. Obok ustaw regulujących kwestie szeroko pojętej ochrony zdrowia obowiązuje także szereg regulacji podstawowych, tj. rozporządzeń oraz aktów prawa miejscowego. Skupiając jednak szczególną uwagę na zagadnieniu będącym przedmiotem niniejszych wywodów, trzeba się odnieść do kwestii zapobiegania oraz zwalczania zakażeń i chorób zakaźnych u ludzi, po pierwsze - w kontekście szczepień ochronnych przeciwko COVID-19, a także po drugie - w zakresie zasad postępowania w ramach ogłoszonego początkowo stanu zagrożenia epidemicznego, jak i istniejącego aktualnie stanu epidemii w Polsce.

Trzymając się tak przyjętego porządku rozważań, w ramach rozwiązań podustawowych w analizowanym zakresie można wskazać przykładowo: uchylone Rozporządzenie Ministra Zdrowia z dnia 13 marca 2020 r. w sprawie ogłoszenia na obszarze Rzeczypospolitej Polskiej stanu zagrożenia epidemicznego ${ }^{32}$, Rozporządzenie Ministra Zdrowia z dnia 20 marca 2020 r. w sprawie ogłoszenia na obszarze Rzeczypospolitej Polskiej stanu epidemii ${ }^{33}$ czy Rozporządzenie Ministra Zdrowia z dnia 15 lutego 2021 r. w sprawie kwalifikacji osób przeprowadzających szczepienia ochronne przeciwko COVID-1934, które utraciło już swą moc. Aktualnie obowiązujące rozporządzenia odnoszące się do COVID-19 poddano analizie w kolejnym punkcie niniejszego artykułu.

Jeśli natomiast chodzi o akty prawa miejscowego, to w ramach ciekawych przykładów można wskazać w tym miejscu: uchwałę Nr XXIII/187/20 z dnia 7 kwietnia 2020 r. Rady Miejskiej w Oleśnie

o zawodzie fizjoterapeuty (tekst jedn. Dz.U. 2021, poz. 553) Ustawa z dnia 24 II 2017 r. o uzyskiwaniu tytułu specjalisty $\mathrm{w}$ dziedzinach mających zastosowanie $\mathrm{w}$ ochronie zdrowia (tekst jedn. Dz.U. 2021, poz. 1297), Ustawa z dnia 27 X 2017 r. o podstawowej opiece zdrowotnej (tekst jedn. Dz.U. 2021, poz. 1050), Ustawa z dnia 7 X 2020 r. o Funduszu Medycznym (Dz.U. poz. 1875), Ustawa z dnia 10 XII 2020 r. o zawodzie farmaceuty (Dz.U. 2021, poz. 97).

${ }^{31}$ Tekst jedn. Dz.U. 2021, poz. 2095.

32 Dz.U. poz. 433.

${ }^{33}$ Dz.U. poz. 491.

${ }^{34}$ Dz.U. poz. 293. 
w sprawie przeciwdziałania sytuacji kryzysowej wywołanej COVID-1935 czy uchwałę Nr XXIX/215/21 z dnia 8 lutego 2021 r. Rady Miejskiej Kudowy-Zdroju w sprawie zwolnień z podatku od nieruchomości z powodu COVID-1936, a także obwieszczenie Wojewody Łódzkiego z dnia 15 stycznia 2021 r. w sprawie wykazu podmiotów udzielających świadczeń opieki zdrowotnej, w tym transportu sanitarnego, w związku z przeciwdziałaniem COVID-1937 czy obwieszczenie Wojewody Świętokrzyskiego z dnia 19 lutego 2021 r. w sprawie wykazu podmiotów wykonujących działalność lecznicza, realizujących szczepienia przeciw COVID-1938.

\section{Rozwiązania przyjęte w związku z epidemią COVID-19}

\subsection{Sposób dystrybucji szczepionek przeciwko SARS-CoV-2}

Rozwiązania w zakresie szczepień ochronnych określone zostały w rozdziale 4 u.z.c.z.l. Zgodnie z regulacją art. 17 obowiązkowym szczepieniom ochronnym przeciw chorobom zakaźnym podlegają osoby, określone w rozporządzeniu ministra właściwego do spraw zdrowia. Osoby, które przebywają na terytorium RP przez okres krótszy niż 3 miesiące, nie są zobowiązane do poddawania się szczepieniom, z wyjątkiem szczepień poekspozycyjnych. Wykonanie szczepienia poprzedza badanie kwalifikacyjne, przeprowadzane w celu wykluczenia przeciwskazań, a w przypadku uzyskania pozytywnego wyniku lekarz wydaje stosowne zaświadczenie, stanowiące podstawę wykonania szczepienia. Jeśli istnieją podstawy do długotrwałego odroczenia szczepienia, lekarz kieruje osobę objętą obowiązkiem szczepienia do konsultacji specjalistycznej. $Z$ analizy tego przepisu wynika, że obowiązek poddania się szczepieniom co do zasady powstaje z mocy prawa (art. 5 ust. 1 pkt 1 lit. b w związku z art. 17 u.z.c.z.l.) i - jak się podkreśla w orzecznictwie NSA - jako bezpośrednio wykonalny, nie wymaga konkretyzacji $\mathrm{w}$ formie decyzji administracyjnej ${ }^{39}$. Wykaz chorób objętych szczepieniem obowiązkowym, podmioty obowiązane do poddania się temu

\footnotetext{
${ }^{35}$ Dz.Urz. Województwa Opolskiego 2020, poz. 1175.

${ }^{36}$ Dz.Urz. Województwa Dolnośląskiego 2021, poz. 743.

${ }^{37}$ Dz.Urz. Województwa Łódzkiego 2021, poz. 238.

${ }^{38}$ Dz.Urz. Województwa Świętokrzyskiego 2021, poz. 814.

${ }^{39}$ Zob. wyrok NSA z 6 IV 2011 r., II OSK 32/11, Legalis nr 367413.
} 
szczepieniu, wiek i inne okoliczności stanowiące przesłankę do nałożenia obowiązku szczepienia, kwalifikacje osób przeprowadzających szczepienia ochronne, sposób przeprowadzania szczepień ochronnych, tryb przeprowadzania konsultacji specjalistycznej dla osób, w przypadku których lekarskie badanie kwalifikacyjne daje podstawy do długotrwałego odroczenia obowiązkowego szczepienia ochronnego, czy stosowne wzory określonych dokumentów w sposób szczegółowy określa rozporządzenie Ministra Zdrowia z dnia 18 sierpnia 2011 r. w sprawie obowiązkowych szczepień ochronnych ${ }^{40}$. W aspekcie podmiotowym do przyjęcia szczepionki są zobowiązane wszystkie osoby przebywające na terytorium RP przez okres dłuższy niż 3 miesiące ( $z$ wyjątkiem tzw. szczepień poekspozycyjnych), zwłaszcza dzieci i młodzież do 19 roku życia. Szczepienia wymagane są co do zasady w zakresie 14 chorób zakaźnych wyliczonych $\mathrm{w} \S 2$ rozporządzenia. Już w tym miejscu należy stwierdzić, że wirus SARS-CoV-2, prowadzący do rozwinięcia się przecież ostrej choroby zakaźnej dróg oddechowych COVID-19, nie został w ramach omawianego aktu wykonawczego objęty obowiązkiem szczepień ochronnych.

Pozostawienie kwestii szczegółowych do regulacji w drodze rozporządzenia zapewnia elastyczność przyjętych rozwiązań i umożliwia szybką ich modyfikację wraz z postępem nauk medycznych oraz zmieniającą się sytuacją epidemiczną kraju. Obowiązek poddania się szczepieniu obejmuje nie tylko, jak trafnie podkreśla doktryna i orzecznictwo, sam akt podania szczepionki, lecz także wszystkie czynności z nim związane, zwłaszcza zaś tzw. badanie kwalifikacyjne poprzedzające podanie preparatu ${ }^{41}$.

W art. 18 ustawy określono natomiast między innymi, że osoby, które nie są uprawnione $z$ tytułu ubezpieczenia zdrowotnego, podlegają szczepieniom ochronnym na koszt państwa. Na marginesie warto wskazać, że Minister Zdrowia, mając na względzie konieczność stworzenia stałego systemu zaopatrzenia w szczepionki podmiotów, które przechowują szczepionki i przeprowadzają szczepienia ochronne, oraz biorąc pod uwagę wymagania Dobrej Praktyki Dystrybucyjnej w rozumieniu przepisów prawa farmaceutycznego i bezpieczeństwa obrotu szczepionkami, wydał w tym zakresie Rozporządzenie z dnia 21 kwietnia 2017 r.

${ }^{40}$ Tekst jedn. Dz.U. 2018, poz. 753.

${ }^{41}$ Zob. np. wyrok NSA z 6 IX 2017 r., II GSK 2399/15, Legalis nr 1652129. Z literatury zob. N. Karczewska-Kamińska, Przymus leczenia i inne interwencje medyczne bez zgody pacjenta, Warszawa 2018, s. 203-204. 
w sprawie zapotrzebowania na szczepionki służące do przeprowadzania szczepień obowiązkowych ${ }^{42}$.

Poza obowiązkowymi szczepieniami ochronnymi ustawodawca określił w art. 19 ustawy także kategorię zalecanych szczepień ochronnych, czyli takich, których zastosowanie nie zostało objęte obowiązkiem, przy czym zgodnie z art. 19 ust. 7 ustawy koszt zakupu szczepionki ponosi osoba poddająca się takiemu szczepieniu, a w przypadku pracowników narażonych na działanie biologicznych czynników chorobotwórczych - pracodawca (art. 20 ust. 3 ustawy), co tworzy w istocie system partycypacji w kosztach świadczeń zdrowotnych, niezgodny z określoną w Konstytucji RP zasadą równego dostępu do tych świadczeń. Minister Zdrowia, uwzględniając zalecenia Światowej Organizacji Zdrowia i cele nadzoru epidemiologicznego, wydał Rozporządzenie z dnia 16 września 2010 r. w sprawie wykazu zalecanych szczepień ochronnych oraz sposobu finansowania i dokumentowania zalecanych szczepień ochronnych wymaganych międzynarodowymi przepisami zdrowotnymi ${ }^{43}$. Wskazany akt wykonawczy w ramach wykazu (zamkniętego katalogu) zalecanych szczepień ochronnych także nie uwzględnia szczepień przeciw COVID-19.

Dokonując oceny opisanej regulacji, należy podkreślić, że delegacja ustawowa dla Ministra Zdrowia została sformułowana w sposób niewłaściwy, ponieważ nie określa kryteriów uznania określonego zakażenia, choroby zakaźnej za chorobę o charakterze epidemicznym, uzasadniających stosowanie do niej przepisów ustawy. Powyższe powoduje niezgodność zarówno przepisów zawierających delegację, jak również rozporządzeń wydanych na ich podstawie z regułami przyzwoitej legislacji.

Ustawą nowelizująca z z dnia 21 stycznia $2021 \mathrm{r}^{44}$ do ustawy dodane zostały między innymi artykuły 21c-21f, odnoszące się do szczepień przeciwko COVID-19. Zgodnie z powyższą regulacja, w przypadku wystąpienia stanu zagrożenia epidemicznego lub stanu epidemii, ogłoszonych z powodu COVID-19, przeprowadzane są szczepienia ochronne, poprzedzone badaniem kwalifikacyjnym w celu wykluczenia przeciwskazań do jego wykonania. Zakup szczepionek oraz koszt

${ }^{42}$ Dz.U. 2017, poz. 848.

${ }^{43}$ Dz.U. 2010 Nr 180, poz. 1215.

${ }_{44}$ Zob. art. 12 Ustawy z dnia 21 I 2021 r. o zmianie ustawy o szczególnych rozwiązaniach związanych z zapobieganiem, przeciwdziałaniem i zwalczaniem COVID-19, innych chorób zakaźnych oraz wywołanych nimi sytuacji kryzysowych oraz niektórych innych ustaw (Dz.U. 2021, poz. 159). 
przeprowadzenia szczepień pokrywany jest ze środków publicznych. Podstawą przeprowadzenia szczepienia jest skierowanie. Dodatkowo ustawa określa warunki utworzenia centralnego elektronicznego systemu rejestracji na szczepienia ochronne przeciwko COVID-19 oraz przetwarzania zgromadzonych w tym systemie danych.

Za niezrozumiałe można uznać posługiwanie się przez ustawodawcę terminem szczepienie przeciwko COVID-19, gdy w rzeczywistości szczepienie dotyczy nie choroby, a wywołującego ją czynnika biologicznego - wirusa SARS-CoV-19.

Minister Zdrowia określił w drodze rozporządzenia: (1) kwalifikacje osób przeprowadzających badanie kwalifikacyjne w celu wykluczenia przeciwwskazań do wykonania szczepienia, przeprowadzane przez lekarza lub osobę posiadającą określone kwalifikacje, (2) kwalifikacje osób przeprowadzających szczepienia ochronne przeciwko COVID-19, są to: fizjoterapeuci, farmaceuci, higienistki szkolne i diagności laboratoryjni, posiadający określone kwalifikacje - uwzględniając konieczność zapewnienia bezpieczeństwa osób poddanych tym szczepieniom. W tej materii obowiązuje Rozporządzenie Ministra Zdrowia z dnia 9 kwietnia 2021 r. w sprawie kwalifikacji osób przeprowadzających badania kwalifikacyjne i szczepienia ochronne przeciwko COVID-1945. Uchwałą Rady Ministrów z dnia 15 grudnia 2020 r. przyjęty został Narodowy Program Szczepień przeciw COVID-1946. W dokumencie tym określono cztery etapy szczepień, wyznaczające kolejność udzielania szczepień ochronnych poszczególnym uprawnionym do tego osobom. Zgodnie $\mathrm{z}$ treścią tego dokumentu, w etapie 0 zaszczepieni mają zostać pracownicy sektora ochrony zdrowia oraz pracownicy pomocy społecznej, w etapie I zaszczepieni mają zostać pensjonariusze placówek pomocy społecznej oraz zakładów opiekuńczo-leczniczych i pielęgnacyjno-opiekuńczych, osoby powyżej 60 roku życia w kolejności od najstarszych, służby mundurowe oraz nauczyciele, w etapie II zaszczepione mają być osoby poniżej 60 lat z chorobami zwiększającymi ryzyko ciężkiego przebiegu COVID-19, w trakcie diagnostyki i leczenia, wymagającego wielokrotnego lub częstego kontaktu z placówkami ochrony zdrowia, oraz osoby zapewniające funkcjonowanie podstawowej działalności państwa i narażone na zakażenie ze względu na częste kontakty społeczne, wreszcie w etapie III mają zostać zaszczepieni wszyscy pozostali dorośli.

${ }^{45}$ Dz.U. 2021, poz. 668.

${ }^{46}$ Zob. https://www.gov.pl/web/szczepimysie/narodowy-program-szczepien-przeciw-covid-19 (dostęp: 28 X 2021). 
Narodowy Fundusz Zdrowia wydał w dniu 18 grudnia 2020 r. Wytyczne dotyczące szczepień przeciw COVID-1947 dla szpitali węzłowych, szpitali niewęzłowych, zakładów opiekuńczo-leczniczych oraz uzdrowisk, w którym powiela powyższą kolejność szczepień.

Trzeba w tym miejscu dodać, że zgodnie z $\$ 1$ najnowszego Rozporządzenia Ministra Zdrowia z dnia 22 grudnia 2021 r. zmieniającego rozporządzenie w sprawie ogłoszenia na obszarze Rzeczypospolitej Polskiej stanu epidemii ${ }^{48}$ dodano nowy rozdział 6a pt. „Obowiązek przeprowadzenia szczepień ochronnych" ${ }^{\prime 9}$. Regulacja ta ma takie znaczenie, że z dobrowolności poddania się szczepieniu przeciwko COVID-19 wyłączono określone grupy osób i są to: (1) osoby wykonujące zawód medyczny w podmiotach wykonujących działalność leczniczą oraz osoby wykonujące czynności zawodowe w tych podmiotach, inne niż wykonywanie zawodu medycznego, (2) osoby zatrudnione oraz osoby

${ }^{47}$ Zob.https://www.nfz.gov.pl/aktualnosci/aktualnosci-centrali/wytyczne-dotyczace-szczepien-przeciw-covid-19-dla-szpitali-wezlowych-szpitali-niewezlowych-zol-i-oraz-uzdrowisk,7881.html (dostęp: 28 X 2021).

${ }^{48}$ Dz.U. 2021, poz. 2398. Zob. tym samym Rozporządzenie Ministra Zdrowia z dnia 20 III 2020 r. w sprawie ogłoszenia na obszarze Rzeczypospolitej Polskiej stanu epidemii (Dz.U. 2020, poz. 491), zwłaszcza rozdział 6a. Obowiązek przeprowadzenia szczepień ochronnych i § $12 \mathrm{a}-\mathrm{b}$.

${ }^{49}$ Według $\S 12$ a ust. 1 . tego rozporządzenia obowiązkowi szczepień przeciwko COVID-19 podlegają: (1) osoby wykonujące zawód medyczny w rozumieniu art. 2 ust. 1 pkt 2 Ustawy z dnia 15 IV 2011 r. o działalności leczniczej (Dz.U. 2021, poz. 711, 1773 i 2120) w podmiotach wykonujących działalność leczniczą oraz osoby wykonujące czynności zawodowe w tych podmiotach, inne niż wykonywanie zawodu medycznego; (2) osoby zatrudnione oraz osoby realizujące usługi farmaceutyczne, zadania zawodowe lub czynności fachowe w aptece ogólnodostępnej lub punkcie aptecznym; (3) studenci kształcący się na kierunkach przygotowujących do wykonywania zawodu medycznego, o którym mowa w art. 68 ust. 1 pkt 1-8 Ustawy z dnia 20 VII 2018 r. - Prawo o szkolnictwie wyższym i nauce (Dz.U. 2021 poz. 478, 619, 1630, 2141 i 2232). Stosownie do ust. 2 osoby, o których mowa w ust. 1, są obowiązane poddać się szczepieniu ochronnemu, którego efektem będzie otrzymanie unijnego cyfrowego zaświadczenia w rozumieniu art. 2 pkt 2 Rozporządzenia Parlamentu Europejskiego i Rady (UE) 2021/953 z dnia 14 VI 2021 r. w sprawie ram wydawania, weryfikowania i uznawania interoperacyjnych zaświadczeń o szczepieniu, o wyniku testu i o powrocie do zdrowia w związku z COVID-19 (unijne cyfrowe zaświadczenie COVID) w celu ułatwienia swobodnego przemieszczania się w czasie pandemii COVID-19 (Dz.Urz. UE L 211 z 15.06.2021, str. 1), w terminie nie późniejszym niż do dnia 1 marca 2022 r. natomiast w myśl ust. 3. obowiązek, o którym mowa w ust. 1, ma zastosowanie także do osób, u których do dnia 1 III 2022 r. upłynie więcej niż 6 miesięcy od uzyskania pozytywnego wyniku testu diagnostycznego w kierunku SARS-CoV-2. Co więcej, zgodnie z \& 12b, obowiązek, o którym mowa w § 12a ust. 1, stosuje się do osób, które nie mają przeciwwskazań do szczepienia w zakresie stanu ich zdrowia. 
realizujące usługi farmaceutyczne, zadania zawodowe lub czynności fachowe w aptece ogólnodostępnej lub punkcie aptecznym, (3) studenci kształcący się na kierunkach przygotowujących do wykonywania zawodu medycznego, m.in. na kierunkach: lekarskim, lekarza dentysty, farmaceuty, pielęgniarki, położnej, diagnosty laboratoryjnego, fizjoterapeuty oraz ratownika medycznego. Obowiązek ten dotyczy określonego terminu, który przypada nie później niż do dnia 1 marca 2022 r. Poza tym obowiązek poddania się szczepieniu ochronnemu przeciwko COVID-19 dotyczy także osób, u których do 1 marca 2022 r. upłynie więcej niż 6 miesięcy od uzyskania pozytywnego wyniku testu diagnostycznego w kierunku SARS-CoV-2. Co więcej, obowiązek poddania się szczepieniu przeciwko COVID-19 stosuje się do osób, które nie mają przeciwwskazań do szczepienia w zakresie stanu ich zdrowia.

\subsection{Ograniczenia, nakazy i zakazy w związku z wystąpieniem stanu epidemii}

Wystąpienie w Polsce stanu epidemii spowodowało ustanowienie wielu ograniczeń, nakazów i zakazów. Aktem prawnym, którym zapoczątkowano wprowadzenie czasowych ograniczeń, nakazów i zakazów, było Rozporządzenie Rady Ministrów z dnia 31 marca 2020 r. w sprawie ustanowienia określonych ograniczeń, nakazów i zakazów w związku z wystąpieniem stanu epidemii ${ }^{50}$. Zgodnie z $\S 1$ tego aktu wykonawczego od dnia 31 marca 2020 r. do odwołania ustala się, że obszarem, na którym wystąpił stan epidemii wywołany zakażeniami wirusem SARS-CoV-2, jest terytorium Rzeczypospolitej Polskiej. Z uwagi na wysoką zachorowalność wywołaną przez zakażenie wirusem SARS-CoV-2 wprowadzano w drodze kolejnych rozporządzeń Rady Ministrów określone ograniczenia, nakazy i zakazy. Uchwalono łącznie szesnaście takich regulacji, noszących ten sam tytu1 ${ }^{51}$, wydanych w okresie 20 miesięcy,

${ }^{50}$ Dz.U.2020, poz. 566.

${ }^{51}$ Są to Rozporządzenia Rady Ministrów w sprawie ustanowienia określonych ograniczeń, nakazów i zakazów w związku z wystąpieniem stanu epidemii: (1) z dnia 31 III 2020 r. (Dz.U. poz. 566), (2) z dnia 10 IV 2020 r. (Dz.U. poz. 658), (3) z dnia 19 IV 2020 r. (Dz.U. poz. 697), (4) z dnia 2 V 2020 r. (Dz.U. poz. 792), (5) z dnia 16 V 2020 r. (Dz.U. poz. 787), (6) z dnia 29 V 2020 r. (Dz.U. poz. 964), (7) z dnia 19 VI 2020 r. (Dz.U. poz. 1066), (8) z dnia 7 VIII 2020 r. (Dz.U. poz. 1356), (9) z dnia 9 X 2020 r. (Dz.U. poz. 1758), (10) z dnia 26 XI 2020 r., (Dz.U. poz. 2091), (11) z dnia 1 XII 2020 r. (Dz.U. poz. 2132), (12) 21 XII 2020 r. (Dz.U. poz. 2316), (13) z dnia 14 I 2021 r. (Dz.U. poz. 91), (14) z dnia 
tj. do dnia zamknięcia stanu prawnego niniejszego artykułu. Postawę prawną do wydania tych rozporządzeń Rady Ministrów stanowi art. 46a i art. 46b pkt 1-6 i 8-12 u.z.c.z.l. Warto przytoczyć treść art. 46a tej ustawy, zgodnie z którym w przypadku wystąpienia stanu epidemii lub stanu zagrożenia epidemicznego o charakterze i w rozmiarach przekraczających możliwości działania właściwych organów administracji rządowej i organów jednostek samorządu terytorialnego, Rada Ministrów może określić, $w$ drodze rozporządzenia, na podstawie danych przekazanych przez Ministra Zdrowia, Ministra Spraw Wewnętrznych, Ministra Spraw Administracji Publicznej, Głównego Inspektora Sanitarnego oraz wojewodów: (1) zagrożony obszar wraz ze wskazaniem rodzaju strefy, na którym wystąpił stan epidemii lub stan zagrożenia epidemicznego, (2) rodzaj stosowanych rozwiązań - w zakresie określonym $\mathrm{w}$ art. $46 \mathrm{~b}^{52}$ - mając na względzie zakres stosowanych rozwiązań oraz uwzględniając bieżące możliwości budżetu państwa oraz budżetów jednostek samorządu terytorialnego.

Dokonując analizy powyżej wskazanych rozporządzeń Rady Ministrów w sprawie ustanowienia określonych ograniczeń, nakazów i zakazów w związku z wystąpieniem stanu epidemii, można wyodrębnić dwa odrębne obszary obostrzeń. W pierwszej kategorii mieści się sposób określonego zachowania się dotyczący m.in.: obowiązku odbycia kwarantanny, ograniczeń określonego sposobu przemieszczania się, ograniczeń w prowadzeniu różnych typów działalności gospodarczej, ustanowienia limitów osób w obiektach handlowych lub usługowych, nakazu określonego sposobu przemieszczania się oraz obowiązku

26 II 2021 r. (tekst jedn. Dz.U. 2021, poz. 447), (15) z dnia 19 III 2021 r. (Dz.U. poz. 512), (16) z dnia 6 V 2021 r. (Dz.U. poz. 861).

${ }^{52}$ Zgodnie $\mathrm{z}$ art. $46 \mathrm{~b}$ u.z.c.z.l.: $\mathrm{w}$ rozporządzeniu, o którym mowa $\mathrm{w}$ art. 46a, można ustanowić: (1) ograniczenia, obowiązki i nakazy, o których mowa w art. 46 ust. 4 [ogłaszanie i odwoływanie stanu zagrożenia epidemicznego lub epidemii - P.S, P.J.]; (2) czasowe ograniczenie określonych zakresów działalności przedsiębiorców; (3) czasową reglamentację zaopatrzenia w określonego rodzaju artykuły; (4) obowiązek poddania się badaniom lekarskim przez osoby chore i podejrzane o zachorowanie; (4a) obowiązek stosowania określonych środków profilaktycznych i zabiegów; (5) obowiązek poddania się kwarantannie; (6) miejsce kwarantanny; (7) (uchylony) (8) czasowe ograniczenie korzystania z lokali lub terenów oraz obowiązek ich zabezpieczenia; (9) nakaz ewakuacji w ustalonym czasie z określonych miejsc, terenów i obiektów; (10) nakaz lub zakaz przebywania w określonych miejscach i obiektach oraz na określonych obszarach; (11) zakaz opuszczania strefy zero przez osoby chore i podejrzane o zachorowanie; (12) nakaz określonego sposobu przemieszczania się; (13) nakaz zakrywania ust i nosa, w określonych okolicznościach, miejscach i obiektach oraz na określonych obszarach, wraz ze sposobem realizacji tego nakazu. 
stosowania środków profilaktycznych, czasowego ograniczenia korzystania z lokali lub terenów oraz obowiązku ich zabezpieczenia, ograniczenia funkcjonowania określonych instytucji lub zakładów pracy, czasowego ograniczenia określonych zakresów działalności przedsiębiorców oraz obowiązku wykonania określonych zabiegów sanitarnych, zakazu organizowania widowisk i innych zgromadzeń ludności, nakazu udostępnienia nieruchomości, lokali i terenów przewidzianych planami przeciwepidemicznymi, czasowego ograniczenia korzystania z lokali lub terenów oraz obowiązek ich zabezpieczenia, ograniczenia, zakazów i nakazów obowiązujących na obszarze, na którym wystąpił stan epidemii, ograniczenia określonego sposobu przemieszczania się oraz obowiązku poddania się kwarantannie i testom diagnostycznym w kierunku SARS-CoV-2. Do drugiej kategorii można zaliczyć obowiązek szczepień ochronnych przeciwko COVID-19, który został wprowadzony przepisami przytoczonego już rozporządzenia Rady Ministrów ${ }^{53}$ i wszedł w życie z dniem 15 stycznia 2021 r. Kolejne regulacje aktów wykonawczych dotyczące szczepień ochronnych przeciwko COVID-19 wprowadzają określoną kolejność poddawania szczepieniom osób, które się do niego kwalifikują. W związku z tym, podmioty przeprowadzające szczepienia ochronne przeciwko COVID-19 mają obowiązek stosowania tych szczepień z zachowaniem powyższej kolejności ${ }^{54}$.

\section{Ocena zgodności sposobu dystrybucji szczepionek przeciwko SARS-CoV-2 z konstytucyjnym modelem ochrony zdrowia}

\subsection{Kryteria oceny dystrybucji szczepionek i kwestia ustanowienia stanu epidemii}

Dokonując oceny zgodności sposobu dystrybucji szczepionek przeciwko COVID-19 z konstytucyjnym modelem ochrony zdrowia, uwagę skupiono na trzech jej aspektach. Przyjęte rozwiązanie skonfrontowano

${ }^{53}$ Rozporządzenie Rady Ministrów z dnia 14 I 2021 r. zmieniające rozporządzenie w sprawie ustanowienia określonych ograniczeń, nakazów i zakazów w związku z wystąpieniem stanu epidemii (Dz.U. 2021, poz. 91).

${ }^{54}$ Zob. w tym zakresie $\S 27 \mathrm{z}$ rozdziału 4. pt. "Szczepienia ochronne przeciwko COVID-19” oraz $\S 28$ pt. „Przepisy przejściowe” aktualnie obowiązującego Rozporządzenia Rady Ministrów z dnia 6 V 2021 r. w sprawie ustanowienia określonych ograniczeń, nakazów i zakazów w związku z wystąpieniem stanu epidemii (Dz.U. 2021, poz. 861). 
z: po pierwsze - zasadą ochrony zdrowia, po drugie - zasadą równego dostępu do świadczeń opieki zdrowotnej finansowanej ze środków publicznych, po trzecie - z wyjątkami konstytucyjnymi.

Zasadne wydaje się $\mathrm{w}$ tym miejscu poddanie ocenie również działania państwa, polegającego na wprowadzeniu stanu epidemii. Trzeba się zgodzić z M. Radajewskim, że "[p]andemia COVID-19, która wybuchła w pierwszej połowie 2020 r., skłoniła władze wielu państw do nadzwyczajnych działań mających zapobiec rozprzestrzenianiu się nowej choroby. Nie ograniczały się one jedynie do usprawnienia funkcjonowania służby zdrowia, ale objęły swoim zakresem także wiele dziedzin życia społecznego, a nawet prywatnego. Dochodziło w ten sposób do ograniczenia praw i wolności człowieka i obywatela na rzadko spotykaną wcześniej skalę. Analogiczne działania zostały podjęte również przez polskie władze. Liczne wątpliwości, jakie wywołały one w debacie publicznej, skłaniają do refleksji naukowej na temat prawnych aspektów ograniczania praw i wolności w związku z epidemią" ${ }^{\prime \prime}$. Odnosząc się zatem do wprowadzonych ograniczeń, nakazów i zakazów w związku z wystąpieniem stanu epidemii, należy przyjąć, że muszą one z jednej strony "respektować zasady limitowania tych praw obowiązujące w normalnych warunkach funkcjonowania państwa"56, w szczególności zgodność tej limitacji z zasadą proporcjonalności, wyrażoną $w$ art. 31 ust. 3 Konstytucji RP. Z drugiej jednak strony wydaje się, że "[d]o zwalczania szczególnie groźnych chorób zakaźnych może być zatem niezbędne jednoczesne obowiązywanie zarówno stanu klęski żywiołowej, jak i stanu epidemii lub stanu zagrożenia epidemicznego $^{\prime \prime 57}$. Pamiętać trzeba, że stan epidemii w świetle Konstytucji RP nie jest stanem nadzwyczajnym ${ }^{58}$, uzasadniającym wprowadzanie daleko idących ograniczeń praw i wolności obywateli oraz ich grup. To przecież stan klęski żywiołowej, będąc jednym z trzech stanów nadzwyczajnych określonych w Konstytucji RP (zob. art. 232), stanowi instytucję wyjątkowa, wprowadzaną wyłącznie w ostatecznych sytuacjach, a przez to pozwalającą na radykalną ingerencję w sferę praw człowieka. Wśród

${ }^{55}$ M. Radajewski, Prawa i wolności człowieka i obywatela w dobie pandemii, w: Pandemia Covid-19 a prawa i wolności obywatela, pod red. T. Gardockiej, D. Jagiełły, Warszawa 2020, s. 77.

${ }^{56}$ Ibidem, s. 82.

${ }^{57}$ Ibidem, s. 91 i n.

${ }^{58}$ L. Bosek, Komentarz do art. 46a, w: Ustawa o zapobieganiu oraz zwalczaniu zakażeń i chorób zakaźnych u ludzi. Komentarz, s. 739 i n. 
innych różnic pomiędzy wprowadzonym stanem epidemii a stanem nadzwyczajnym można wymienić to, iż obowiązujące w polskim prawie regulacje art. 46a i 46b u.z.c.z.l. "[...] ograniczyły zakres swobodnego uznania Rady Ministrów przy ocenie konieczności ogłoszenia stanu nadzwyczajnego, wyznaczony normami Konstytucji RP (art. 228 Konstytucji RP), ponieważ upoważnienie Rady Ministrów do wydawania rozporządzeń ustanawiających czasowe ograniczenia, zakazy i nakazy przeciwepidemiczne - zgodnie z zasadą proporcjonalności z art. 228 ust. 1 Konstytucji RP - ogranicza możliwość stwierdzenia, że w ogóle celowe i dopuszczalne jest wprowadzenie stanu nadzwyczajnego ze względu na zagrożenie epidemiczne" ${ }^{\prime \prime}$. Przepis art. 46a u.z.c.z.l. realizuje więc konstytucyjną zasadę proporcjonalności działania władzy publicznej. Co więcej, odnosząc się do kwestii wejścia w życie rozporządzenia Rady Ministrów w sprawie ustanowienia określonych ograniczeń, nakazów i zakazów w związku z wystąpieniem stanu epidemii to nie występuje tu warunek w zakresie jego wejścia w życie czy dalszego obowiązywania poprzez zatwierdzenie przez Sejm, jak to ma miejsce w przypadku instytucji stanów nadzwyczajnych. Stan epidemii znajduje się zatem poza kontrolą władzy ustawodawczej.

\subsection{Wnioski de lege lata i postulaty de lege ferenda}

Przede wszystkim należy zauważyć, że uchwała Rady Ministrów regulująca kolejność szczepień nie stanowi źródła prawa, zgodnie bowiem $z$ art. 93 ust. 1 Konstytucji RP, uchwały mają charakter wewnętrzny i obowiązują wyłącznie jednostki organizacyjne, podległe organowi, który wydał taki akt. Poza tym, określona w omawianym akcie kolejność wykonywania szczepień pozostaje w sprzeczności zarówno z konstytucyjną zasadą równego dostępu do świadczeń zdrowotnych, finansowanych ze środków publicznych, jak i określonymi od tej zasady wyjątkami. Nawet bowiem przyjęcie zaproponowanej w niniejszym artykule rozszerzającej wykładni wyjątków od zasady równego dostępu do świadczeń nie uprawnia do udzielania szczególnej opieki zdrowotnej pracownikom służby zdrowia, pracownikom służb mundurowych czy nauczycielom, nie wynika to bowiem z urzeczywistniania przez organy państwa zasad sprawiedliwości społecznej. Można oczywiście bez trudu wskazać na

${ }^{59}$ Ibidem. 
inne uzasadnienia dla takiego sposobu dystrybucji szczepionek, na przykład zwiększone ryzyko przenoszenia wirusa przez określone grupy zawodowe, konieczność zaangażowania należących do nich osób do działań, zwiększających możliwość zarażenia się czy wreszcie uznanie przez ustawodawcę istotności poszczególnych grup i osób dla zapewnienia sprawnego funkcjonowania państwa, w szczególności w obszarze ochrony zdrowia. Tym niemniej, powyższe uzasadnienia wykraczają poza określone w art. 68 ust. 3 Konstytucji RP wyjątki, uprawniające do pozytywnej dyskryminacji. Niezrozumiałe i niezgodne z konstytucyjną zasadą ochrony zdrowia było także początkowe całkowite pominięcie w programie szczepień przeciwko COVID-19 osób, które ukończyły 16 rok życia, a nie ukończyły 18 lat. Jak wynika z informacji przekazanych przez producentów szczepionek, niektóre z nich można stosować już od 16 roku życia.

W tej sytuacji należy uznać, że w wymiarze normatywnym nie funkcjonuje żaden system udzielania szczepień ochronnych, a zatem nie ma powodu, by odmawiać wydania skierowania na szczepienie osobom, które nie zostały uwzględnione w aktualnym etapie, określonym przez Radę Ministrów. Istotnym zagadnieniem wydaje się ustalenie, czy można zrekonstruować obowiązek władz państwowych do uchwalenia w tym zakresie stosownej regulacji prawnej.

Zgodnie z brzmieniem art. 228 ust. 1 Konstytucji RP, przesłanką do wprowadzenia odpowiedniego stanu nadzwyczajnego jest wystąpienie szczególnych zagrożeń, wobec których zwykłe środki konstytucyjne są niewystarczające. W myśl obowiązujących przepisów konstytucyjnych, stany nadzwyczajne wprowadzane są jednak wyłącznie fakultatywnie, na co wskazuje zastosowanie przez ustrojodawcę słowa może. Tym samym władze publiczne nie są zobowiązane do wprowadzenia w obecnej sytuacji stanu wyjątkowego, jeśli w ich ocenie nie jest to niezbędne.

Tym niemniej, korelatem prawa do ochrony zdrowia, określonego w art. 68 Konstytucji RP jest obowiązek państwa w zakresie utrzymywania odpowiedniego systemu świadczeń zdrowotnych, finansowanych ze środków publicznych. Zgodnie natomiast $\mathrm{z}$ art. 146 ust. 4 pkt 1 Konstytucji RP, Rada Ministrów zobowiązana jest do zapewnienia wykonania ustaw. Niepodejmowanie zgodnych z przepisami Konstytucji RP działań przez Radę Ministrów oraz Ministra Zdrowia musi być zatem ocenione negatywnie. Prowadzi to bowiem do sytuacji, w której system dystrybuowania szczepionek na niebezpieczna, bezpośrednio zagrażającą życiu chorobę, opiera się o pozaprawne reguły o niejasnym charakterze. 
Co prawda powyższe reguły mogą być poprawne z punktu widzenia reguł zwalczania epidemii czy praktykowania medycyny, ale ich zasadnicza słabość w postaci braku możliwości egzekwowania przez aparat państwowy przyczynia się do tego, że podjęte środki nie są w pełni skuteczne i nie zabezpieczają życia i zdrowia obywateli.

Należy także podkreślić, że nawet w przypadku niewprowadzenia stanu wyjątkowego możliwe jest stosunkowo szybkie wprowadzenie obowiązku szczepień przeciwko COVID-19. Jak już wspomniano, czynniki chorobotwórcze, które podlegają przymusowym szczepieniom, wyszczególnione zostały w wykazie, stanowiącym załącznik do ustawy o zapobieganiu oraz zwalczaniu zakażeń i chorób zakaźnych u ludzi. Wystarczające jest dokonanie nowelizacji tego załącznika przez Ministra Zdrowia, aby szczepienie przeciwko COVID-19 stało się obowiązkiem, podlegającym przymusowi państwowemu. Takie działanie, wobec niskiej obecnie liczby osób poddających się szczepieniu w sposób dobrowolny, wydaje się obecnie niezbędne.

\section{Podsumowanie}

Wprowadzony w Polsce stan epidemii wiąże się z wieloma ograniczeniami, nakazami czy zakazami. Dochodzi do ograniczenia praw i wolności człowieka i obywatela. Jednakże biorąc pod uwagę zagrożenia, jakie wynikaja z epidemii koronawirusa SARS-CoV-2 powodującego chorobę zakaźną COVID-19, trudno negatywnie ocenić wdrożenie stanu przeciwepidemicznego, pomimo sformułowanych wcześniej zastrzeżeń. Bez wątpienia najbardziej istotnym mankamentem jest brak podstawy prawnej uzasadniającej wprowadzenie powszechnego obowiązku stosowania środków profilaktycznych, takich jak np. zasłanianie ust i nosa w przestrzeni publicznej czy obowiązek poddawania się kwarantannie lub izolacji. Do tej pory był widoczny także brak podstawy prawnej do prowadzenia programu szczepień ochronnych przeciwko COVID-19, które mają mieć charakter obowiązkowy. Aktualnie pewne zmiany w kontekście szczepień przeciwko COVID-19 wynikają z najnowszych regulacji ograniczających dobrowolność w tym zakresie. Otóż obowiązkowi przedmiotowych szczepień podlegają określone grupy osób (osoby wykonujące zawód medyczny w podmiotach wykonujących działalność leczniczą oraz osoby wykonujące czynności zawodowe w tych podmiotach, inne niż wykonywanie zawodu medycznego, jak 
i osoby zatrudnione oraz osoby realizujące usługi farmaceutyczne, zadania zawodowe lub czynności fachowe w aptece ogólnodostępnej lub punkcie aptecznym czy studenci kształcący się na kierunkach przygotowujących do wykonywania zawodu medycznego). Obowiązek poddania się temu szczepieniu przypada nie później niż na dzień 1 marca 2022 r. Ponadto obowiązek ten ma zastosowanie także do osób, u których do dnia 1 marca 2022 r. upłynie więcej niż 6 miesięcy od uzyskania pozytywnego wyniku testu diagnostycznego w kierunku SARS-CoV-2. Co ważne, obowiązek szczepień ochronnych przeciwko COVID-19 stosuje się do osób, które nie mają przeciwwskazań do szczepienia w zakresie stanu ich zdrowia.

Powyższe uchybienia są niepokojące o tyle, że utrudniają sprawne wyegzekwowanie poszczególnych ograniczeń, co może wpływać na niedostateczny zakres ich stosowania. Dodatkowo, w warunkach stosowania rozwiązań jawnie sprzecznych z treścią ustawy zasadniczej może następować rozmycie odpowiedzialności urzędników państwa, którzy zajmują się ich wdrażaniem.

\section{LEGAL REGULATIONS IN THE FIELD OF PROTECTIVE VACCINATIONS AGAINST COVID-19 - SELECTED PROBLEMS}

\section{Sum mary}

Undoubtedly, the end of 2019 will be recorded in the annals of modern human history as a time which resulted in an unprecedented event. This is because this year, the global epidemic of the SARS-CoV-2 virus broke out. This virus, on the other hand, leads to the development of an acute infectious disease of the respiratory tract, known as COVID-19. Therefore, the state of epidemic threat that was initially introduced in Poland, and then transformed into the current epidemic state, requires a particular reaction from the state authorities and also, it would seem, an appropriate response to the situation by the citizens themselves. In such exceptional circumstances, the obligation arises for the state to protect the life and health of its citizens, both in the area of enacting the relevant law and its implementation. However, there is a remedy for the growing number of new cases of COVID-19 and deaths in this context, namely the possibility of performing preventive vaccinations against this disease.

This article aims to analyze and evaluate the legal regulations on preventive vaccinations against COVID-19 introduced in Poland. In this regard, reference is made to the basic assumptions used in the constitutional model of health care in Poland. In this context, the principle of equal access to health care services financed from public funds and the constitutional exceptions to the principle of equal access to benefits, such as children, pregnant women, disabled and elderly people 
are discussed, as well as the principle of the active role of the state in combating epidemic threats. These considerations are complemented by an outline of the statutory and sub-statutory solutions in the health care model. The analysis also covers legal solutions adopted with regard to the COVID-19 epidemic, and presents the distribution of SARS-CoV-2 vaccines as well as restrictions, orders and bans in connection with the epidemic. In addition, the compliance of the distribution of SARS-CoV-2 vaccines with the constitutional model of health protection is assessed, with the criteria for assessing this distribution in the context of establishing the state of the epidemic being singled out.

Keywords: preventive vaccinations - health protection - SARS-CoV-2 virus COVID-19 - state of the epidemic - restrictions, orders and bans

\section{LITERATURA}

Bagińska E., Odpowiedzialność za brak dostępności do świadczeń zdrowotnych należnych w ramach systemu opieki zdrowotnej finansowanej ze środków publicznych. Odpowiedzialność podmiotów będących organizatorami systemu opieki zdrowotnej za brak dostępności świadczeń zdrowotnych, w: Odpowiedzialność prywatnoprawna. System Prawa Medycznego, t. 5, pod red. E. Bagińskiej, Warszawa 2021.

Bagińska E., Bączyk-Rozwadowska K., Drozdowska U., Karczewska-Kamińska N., Krupa-Lipińska K., Odpowiedzialność cywilna za szkody wyrządzone przy leczeniu (w związku z udzielaniem świadczeń zdrowotnych). Odpowiedzialność za szkody doznane w następstwie szczepień ochronnych, w: Odpowiedzialność prywatnoprawna. System Prawa Medycznego, t. 5, pod red. E. Bagińskiej, Warszawa 2021.

Banaszak B., Komentarz do art. 68, w: Konstytucja Rzeczypospolitej Polskiej. Komentarz, Warszawa 2012.

Banaszak B., Konstytucja Rzeczypospolitej Polskiej. Komentarz, Warszawa 2009.

Bosek L., Komentarz do art. 46a, w: Ustawa o zapobieganiu oraz zwalczaniu zakażeń i chorób zakaźnych u ludzi. Komentarz, pod red. L. Boska, Warszawa 2021.

Bosek L., Komentarz do art. 5, w: Ustawa o zapobieganiu oraz zwalczaniu zakażeń i chorób zakaźnych u ludzi. Komentarz, pod red. L. Boska, Warszawa 2021.

Bosek L., Komentarz do art. 68, w: Konstytucja RP. Tom I. Komentarz do art. 1-86, pod red. M. Safjana, L. Boska, Warszawa 2016.

Dercz M., Izdebski H., Organizacja ochrony zdrowia Rzeczypospolitej Polskiej w świetle obowiazującego ustawodawstwa, Warszawa-Poznań 2001.

Dercz M. (red.), Izdebski H., Rek T., Prawo publiczne ochrony zdrowia, Warszawa 2013.

Kaczocha M., Redagowanie aktów podustawowych. Zagadnienia praktyczne, Warszawa 2020.

Karczewska-Kamińska N., Przymus leczenia i inne interwencje medyczne bez zgody pacjenta, Warszawa 2018.

Kostyńska M., Koronawirus SARS-CoV-2 - stowniczek pojęć, które warto znać, https:// www.medonet.pl/zdrowie,koronawirus-sars-cov-2---slowniczek-pojec-ktore-warto znac,artykul,70847711.html (dostęp: 28 X 2021).

Lach D.E., Zasada równego dostępu do świadczeń opieki zdrowotnej, Warszawa 2011. 
Michalska-Badziak R., Ochrona zdrowia. Zagadnienia ogólne, w: Prawo administracyjne materialne, pod red. Z. Duniewskiej, B. Jaworskiej-Dębskiej, M. Stahl, Warszawa 2014.

Nosko J., Promocja zdrowia i ochrona zdrowia jako zadanie własne samorzadu terytorialnego, cz. 1, "Zdrowie Publiczne" 2000, nr 4.

Nosko J., Promocja zdrowia i ochrona zdrowia jako zadanie własne samorzadu terytorialnego, cz. 2, "Zdrowie Publiczne” 2000, nr 5.

Prokop K., Prawo do ochrony zdrowia w świetle art. 68 Konstytucji RP, w: Uwarunkowania prawne, ekonomiczne i socjologiczne funkcjonowania wybranych systemów ochrony zdrowia, pod red. T. Mróz, Białystok 2011.

Radajewski M., Prawa i wolności człowieka i obywatela w dobie pandemii, w: Pandemia Covid-19 a prawa i wolności obywatela, pod red. T. Gardockiej, D. Jagiełły, Warszawa 2020.

Wojtczak K., Kompetencje i zadania jednostek samorzadu terytorialnego w zakresie bezpieczeństwa zdrowia ludności, "Studia Prawa Publicznego" 2018, nr 3(23). 